Gut, 1986, 27, 1143-1146

\title{
Dose related in vitro effects of ranitidine and cimetidine on basal and ACTH-stimulated steroidogenesis
}

\author{
C J KENYON, R FRASER, G G BIRNIE, J M C CONNELL, AND \\ A F LEVER \\ From the MRC Blood Pressure Unit and Department of Medicine, Western Infirmary, Glasgow
}

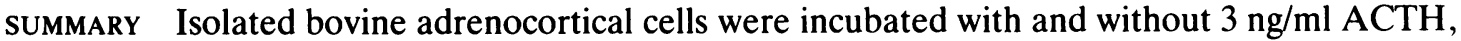
with various concentrations $(10-1000 \mu \mathrm{g} / \mathrm{ml})$ of either cimetidine or ranitidine. Cortisol, corticosterone, and deoxycorticosterone outputs were measured. Cimetidine and ranitidine at 320 and $1000 \mu \mathrm{g} / \mathrm{ml}$ inhibited ACTH-stimulated corticosterone and cortisol synthesis and cimetidine decreased basal cortisol synthesis. The inhibitory effects of cimetidine on cortisol synthesis were approximately 10 times greater than those of ranitidine. Cimetidine $(1000 \mu \mathrm{g} / \mathrm{ml})$, but not ranitidine increased deoxycorticosterone synthesis by ACTH-stimulated cells, indicating inhibition of 11 $\beta$-hydroxylation in the adrenal steroidogenic pathway. Although doses of cimetidine and ranitidine which produce these in vitro effects are much greater than plasma concentrations in normal clinical use, they might be important in acutely ill patients given intravenous bolus injections of cimetidine, or if either antagonist were accumulated by the adrenal to produce high intracellular concentrations.

The imidazole $\mathrm{H}_{2}$ receptor antagonist, cimetidine, prolongs the half-life of many drugs which are normally oxidized by the liver, ${ }^{1-3}$ by inhibition of the microsomal cytochrome P450-dependent monooxygenase system. ${ }^{4}$ Other imidazole drugs such as etomidate, ketoconazole and omeprazole (an inhibition of the gastric proton pump) have recently been shown to inhibit steroid synthesis by blocking cytochrome P450-dependent reactions in the adrenal cortex ${ }^{5-7}$ and it is possible that cimetidine inhibits adrenal steroidogenesis by a similar mechanism.

The dose related effects of cimetidine on basal and ACTH-stimulated cortisol, corticosterone, and deoxycorticosterone synthesis were compared with those of a non-imidazole $\mathrm{H}_{2}$-receptor antagonist, ranitidine, which does not interfere with hepatic metabolism of other drugs ${ }^{8}$ and shows little affinity for hepatic cytochrome P450.

\section{Methods}

MATERIALS

Isolated zona fasciculata/reticularis cells were

Address for correspondence: Dr C J Kenyon. MRC Blood Pressure Unit. Western Infirmary, Glasgow, GII 6NT.

Received for publication 27 January 1986. prepared from minced slices of the inner adrenal cortices of six bovine adrenals by collagenase digestion using the method of Kenyon et al $t^{6}$ adapted from Haning et al. ${ }^{10}$ Aliquots $(200 \mu \mathrm{l})$ of a cell suspension containing $7 \times 10^{5}$ cells $/ \mathrm{ml}$ were added to $0.8 \mathrm{ml}$ medium 199 containing various concentrations. of cimetidine/ranitidine or vehicle, with or without $3 \mathrm{ng} / \mathrm{ml}$ ACTH (Synacthen, Ciba-Geigy). Cells were incubated at $37^{\circ} \mathrm{C}$ for one hour in an atmosphere of $95 \% \mathrm{O}_{2}: 5 \% \mathrm{CO}_{2}$, then centrifuged at $2000 \mathrm{~g}$ for $10 \mathrm{~min}$ at $0^{\circ} \mathrm{C}$ and the supernatant stored at $-20^{\circ} \mathrm{C}$. Cortisol was measured by direct radioimmunoassay using antiserum from the Scottish Antibody Production Unit. Cross reactivities with the cortisol antiserum were $0.2 \%$ for corticosterone, $0.03 \%$ for 11 -deoxycorticosterone and $0.58 \%$ for 11 -deoxycortisol. Corticosterone and deoxycorticosterone were measured by radioimmunoassay after extraction with methylene chloride followed by paper chromatography. " Statistical comparisons were by analysis of variance using Neuman-Keul's multiple range test. ${ }^{12}$

\section{Results}

The effects of increasing concentrations of ranitidine 
and cimetidine on cortisol, corticosterone, and deoxycorticosterone synthesis are shown in the Figure.

CORTISOL.

Basal cortisol synthesis was inhibited by cimetidine at concentrations from $100 \mu \mathrm{g} / \mathrm{ml}(\mathrm{p}<0 \cdot 05)$ but not by ranitidine. Both cimetidine and ranitidine inhibited ACTH-stimulated cortisol synthesis. At concentrations of 320 and $1000 \mu \mathrm{g} / \mathrm{ml}$ the effects of cimetidine were more marked than ranitidine $(p<0 \cdot(01)$. The concentration of drug required for
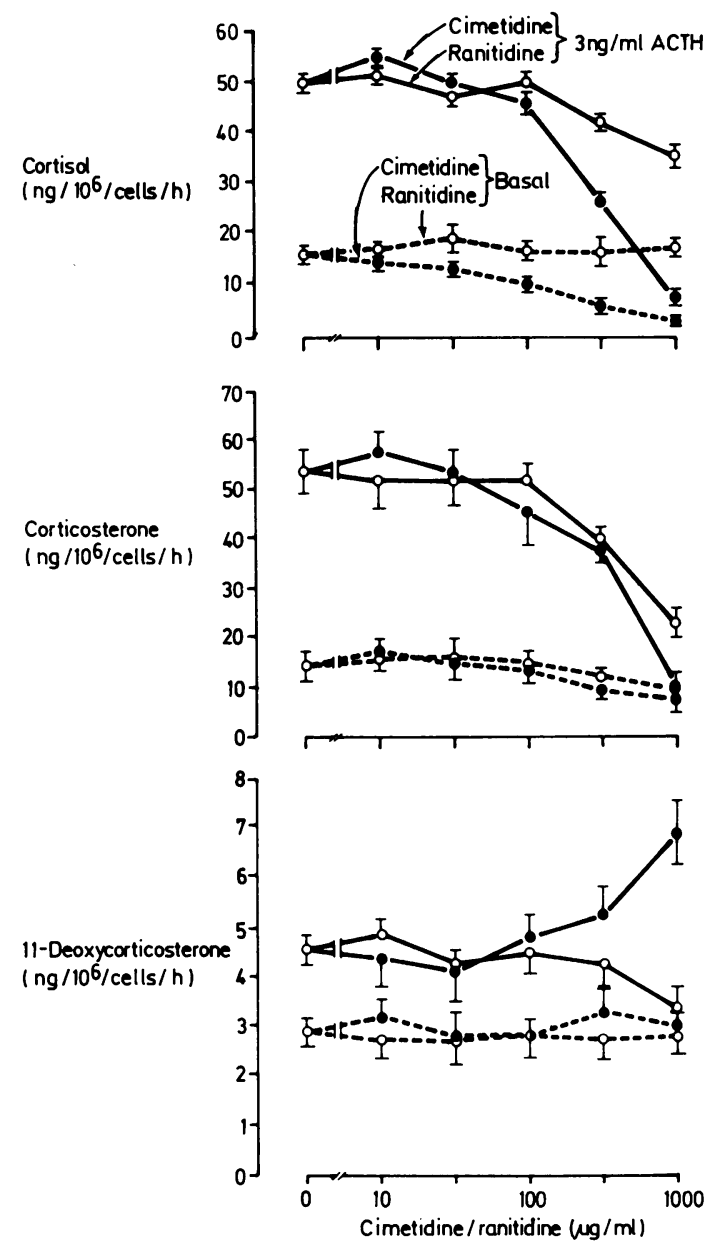

Figure Dose-related effects of cimetidine (O) and ranitidine $(\mathrm{O})$ on cortisol, corticosterone and deoxycorticosterone synthesis by isolated bovine adrenocortical cells. Values shown are means ( \pm SEM, $n=8$ ) of steroid measurements in the incubation medium of cells treated with (solid lines) and without (broken lines) 3 $n g / m l$ ACTH.
$50 \%$ inhibition of cortisol synthesis (IC50) was $200 \mu \mathrm{g}$ cimetidine $/ \mathrm{ml}$ for basal and ACTH-stimulated and $1900 \mu \mathrm{g}$ ranitidine/ml for ACTH-stimulated cells.

\section{CORTICOSTERONE}

The patterns of corticosterone inhibition with ranitidine and cimetidine were broadly similar to those of cortisol, although inhibitory effects of cimetidine at $320 \mathrm{ng} / \mathrm{ml}$ were not significantly different from ranitidine. Cimetidine at $1000 \mu \mathrm{g} / \mathrm{ml}$ inhibited ACTH-stimulated corticosterone synthesis more than ranitidine $(p<0.05)$. IC50s for ACTHstimulated synthesis were $480 \mu \mathrm{g} / \mathrm{ml}$ for cimetidine and $600 \mu \mathrm{g} / \mathrm{ml}$ for ranitidine.

\section{DEOXYCORTICOSTERONE}

Deoxycorticosterone synthesis by cells treated with $1000 \mu \mathrm{g} / \mathrm{ml}$ ranitidine was not stimulated by ACTH. In contrast cimetidine treated, ACTH-stimulated cells secreted $50 \%$ more deoxycorticosterone than ACTH- stimulated control cells and $12 \%$ more than ranitidine treated cells.

\section{Discussion}

The present finding that cimetidine in vitro inhibits both basal and ACTH-stimulated cortisol synthesis by isolated bovine adrenocortical cells is consistent with the observations of De Natale et al ${ }^{1.3}$ who noted that cimetidine treatment lowered plasma corticosterone in stressed and unstressed rats. These data are compatible with the theory that cimetidine directly inhibits adrenocortical function. The site of action of cimetidine's inhibitory effects is indicated from an analysis of the secretory pattern of other adrenocorticosteroids. Reduction of cortisol synthesis was associated with a similar change in corticosterone synthesis and an increase in deoxycorticosterone synthesis, indicating that cimetidine's effects are partly due to inhibition of the $11 \beta$ hydroxylation step. Other imidazole drugs (ketoconazole, etomidate and omeprazole) have effects on steroidogenesis which include inhibition of this cytochrome P450-dependent enzyme. Cimetidine's effect on the hepatic catabolism of other drugs is related to an interaction with cytochrome $\mathrm{P} 450$ and its inhibition of adrenal $11 \beta$-hydroxylase is probably attributable to the same mechanism. Ranitidine, however, a non-imidazole compound, has been shown to have no effect on hepatic cytochrome P450-dependent drug metabolism. Although steroidogenesis was slightly impaired by ranitidine in ACTH-treated cells, there was no evidence of $11 \beta$-hydroxylase inhibition. The difference between the ability of ranitidine and cimetidine to inhibit corticosterone synthesis is less marked than for 
cortisol synthesis. The effects of cimetidine and ranitidine on basal corticosterone synthesis were not significantly different; cimetidine inhibition of ACTH-stimulated corticosterone synthesis was greater than that of ranitidine only at the highest drug concentration used. It is possible that cimetidine has a proportionately greater effect on $17 \alpha$ hydroxylase than ranitidine although the IC50 for corticosterone inhibition by cimetidine is only slightly greater than that for cortisol. Corticosterone biosynthesis was more severely affected by ranitidine than cortisol biosynthesis while synthesis of corticosterone's precursor 11-deoxycorticosterone was not significantly inhibited. Further studies of this interesting discrepancy are required. The lack of effect by ranitidine on basal steroidogenesis and the very high concentration required for inhibitory effects on cortisol secretion indicated a non-specific interference in the mechanism of ACTH action unrelated to an interaction with cytochrome $\mathrm{P} 450$.

The IC50 for ranitidine in these experiments is at least 4000 times greater than peak plasma concentrations during normal therapeutic use. ${ }^{1+}$ In vitro studies with isolated perfused zona glomerulosa cells using a concentration of $0.35 \mu \mathrm{g}$ ranitidine $/ \mathrm{ml}$ found no effect on ACTH-stimulated aldosterone synthesis but an increase in basal secretion and a much reduced angiotensin II response. ${ }^{15}$ More recently, Sancho et al ${ }^{16}$ have shown that $300 \mathrm{mg}$ ranitidine/day for three days reduced plasma cortisol and aldosterone concentrations in sodium deplete, normal man. Perhaps differences both in the effects seen and concentration of drug required are related to the different species used in these studies.

The IC50 for inhibition of cortisol synthesis by cimetidine is only 100 -fold greater than peak plasma concentrations in normal use. ${ }^{17}$ De Natale et al $l^{1.3}$ have suggested that cimetidine is accumulated by the adrenal gland in vivo. If sufficiently high concentrations were achieved this could be of clinical importance, particularly in long term prophylactic treatment of intensive care patients. Similarly, bolus intravenous injections of cimetidine to treat acute gastric bleeding may transiently raise plasma concentrations high enough to blunt the normal adrenocortical response to haemorrhagic stress.

In summary, very high concentrations of cimetidine and ranitidine inhibit adrenal steroidogenesis in vitro. The effect is more marked for cimetidine than ranitidine as cimetidine inhibits the $11 \beta$-hydroxylase in the steroidogenic pathway whereas ranitidine does not. Because ranitidine has been reported as being 10 times more potent than cimetidine as an inhibitor of the $\mathbf{H}_{2}$-receptor, cimetidine is more likely to have side effects on adrenocorticosteroid synthesis. These observations may be clinically important and merit further study.

\section{References}

1 Serlin MJ, Sibean RG, Mossman S. et al. Cimetidine: interaction with oral anticoagulants in man. Lancet 1979; ii: 317-9.

2 Klotz U, Reimann I. Delayed clearance of diazepam due to cimetidine. $N$ Engl J Med 1980; 302: 1012-4.

3 Roberts RK, Grice J, Wood L, Penoff V, McGuffie C. Cimetidine impairs the elimination of theophylline and antipyrine. Gastroenterology 1981; 81: 19-21.

4 Reilly PEB, Carrington LE, Winzor DJ. Interaction of cimetidine with rat liver microsomes. Biochem Pharmacol 1983; 32: 831-5.

5 Loose DS, Kan PB. Hirst MA. Marcus RA. Feldman D. Ketoconazole blocks adrenal steroidogenesis by inhibiting cytochrome P45()-dependent enzymes. J (lin Invest 1983; 71 : 1495-9.

6 Kenyon CJ, Young J, Gray CE, Fraser R. Inhibition by etomidate of steroidogenesis in isolated bovine adrenal cells. J Clin Endoc Metab 1984; 58: 947-8.

7 Howden CW, Kenyon CJ, Beastall GH, Reid JL. Inhibition by omeprazole of adrenocortical response to ACTH: clinical studies and experiments on bovine adrenal cortex in vitro. (in Sci 1986: 70: 99-10?

8 Hénry DA, MacDonald IA, Kitchingman G, Ball GD. Langman MJS. Cimetidine and ranitidine: comparison of effects on hepatic drug metabolism. $\mathrm{Br}$ Med J 1980); 281: $775-7$.

9 Brittain RT, Daly MJ, Jack D, Martin LE, Stables R. Sutherland ML. The outline of the animal pharmacology of ranitidine. In: Misiewicz JJ. Wormsley KG, eds The clinical use of ranitidine (Second International Symposium on Ranitidine. 1981). Oxford: The Medicine Publishing Foundation. 1982: $1-10$.

10 Haning R, Tait SAS, Tait JF. In vitro effect of ACTH, angiotensins, serotonin and potassium on steroid output and conversion of corticosterone to aldosterone by isolated adrenal cells. Endocrinology 1970; 86: 1147-67.

11 Fraser R, Guest S, Holmes E, Mason PA, Wilson AL, Young J. Comparison of radioimmunoassay and physico-chemical means of estimating plasma aldosterone and plasma 11-deoxycorticosterone concentration. In: Cameron EHD, Hiller SG, Griffiths K eds. Steroid immunoassay (Fifth Tenovus Workshop. Cardiff, 1975). Cardiff: Alpha Omega Publishing Ltd, 1975: 283-92.

12 Newman $D$. The distribution of range in samples from a normal population expressed in terms of an independent estimate of standard deviation. Biometrika 1939: 31: 20-30

13 De Natale G, Vacca M, Prezosi P. Cimetidine and adrenals. Drug Res 1980; 30:(11): 1635-6.

14 Woodings EP, Dixon GT. Harrison CC, Convey P, Richards DA. Ranitidine-a new $\mathrm{H}_{2}$-receptor antagonist. Gut 1980); 21: 187-91.

15 Edwards CRW, Yeo T, Delitala G, Al Dujaili EAS, Boscaro M. Besser GM. In vitro studies on the effects 
of ranitidine on isolated anterior pituitary and adrenal cells. Scand J Gastroenterol 1981; 16: suppl 69: 75-7.

16 Sancho JM, Garcia Robles R, Mancheno E, Paya C, Rodicio JL, Ruilope L. Interference by ranitidine with aldosterone secretion in vivo. Eur J Clin Pharmacol 1984; 27: 495-7.
17 Rowley-Jones D, Burland WL, Griffiths R. Pharmacokinetics and pharmacological properties of cimetidine. In: Creutzfeldt W, ed. Proceedings of an international symposium on histamine $\mathrm{H}_{2}$-receptor antagonists. Amsterdam and Oxford: Excerpta Medica 1978: 72-8. 